\title{
PENGARUH OLAHRAGA TREADMILL TERHADAP \\ KONSENTRASI GAS ASETON (DIABETESMELLITUS BIOMARKER) PADA GAS HEMBUS MANUSIA
}

\author{
Nurul Muyasaroh \\ Fakultas Teknik Lingkungan \\ nurulmuyasaroh@ity.ac.id
}

\begin{abstract}
ABSTRAK
Penderita diabetes mellitus dianjurkan untuk melakukan terapi olahraga. Penyakit diabetes mellitus memiliki penanda biologis berupa gas aseton. Penelitian ini bertujuan untuk mengetahui perubahan konsentrasi gas aseton pada gas hembus seseorang sebelum dan setelah berjalan di atas treadmill, menggunakan spektrometer fotoakustik laser $\mathrm{CO}_{2}$. Penelitian ini bermanfaat untuk mengetahui apakah benar olahraga dapat menurunkan kadar glukosa dalam darah. Konsentrasi gas aseton pada gas hembus orang setelah berjalan di atas treadmill mengalami penurunan sebesar 38\% hingga $60 \%$ dibandingkan dengan sebelum berjalan di atas treadmill.
\end{abstract}

Kata kunci: diabetes melitus, olahraga, gas aseton, kadar glukosa.

\section{EFFECT OF TREADMILL EXERCISE ON ACETONE GAS CONCENTRATION (DIABETES MELLITUS BIOMARKER) IN HUMAN BREATH}

\begin{abstract}
Diabetes mellitus patient encouraged to do sports therapy. Diabetes mellitus have a biological marker, acetone gaseous. This study aims to determine the changes in gas concentration of acetone in human breath before and after exercising on a treadmill, using a $\mathrm{CO}_{2}$ laser photoacoustic spectrometer. This research is helpful to know whether exercise can reduce blood glucose levels. The acetone gas concentration in human breath after exercising on a treadmill decreased by $38 \%$ to $60 \%$ than before.
\end{abstract}

Keywords: diabetes mellitus, sports, acetone gas, glucose levels.

\section{A. PENDAHULUAN}

Gas aseton merupakan gas penanda biologis penyakit diabetes melitus. Pankreas penderita diabetes melitus tidak dapat memproduksi insulin yang cukup untuk menyerap glukosa yang diperoleh dari makanan. Kadar glukosa yang 
berlebih di dalam darah penderita diabetes melitus, menyebabkan terjadinya pembentukan gas aseton. Gas aseton tersebut terdapat pada hati dan paru-paru sehingga dapat dideteksi melalui pernapasan.

Penderita diabetes melitus dianjurkan untuk melakukan olahraga. Olahraga teratur dapat menurunkan kadar glukosa dalam darah.Salah satu contoh dari olahraga teratur adalah berjalan $\mathrm{di}$ atas treadmill. Treadmill dilengkapi dengan sistem deteksi jarak, kecepatan dan waktu, sehingga seseorang dapat menentukan berapa jarak, kecepatan dan durasi olahraga yang akan dilakukannya.

Penelitian ini bertujuan untuk mengetahui perubahan konsentrasi gas aseton pada gas hembus seseorang sebelum dan setelah berjalan di atas treadmill menggunakan spektrometer fotoakustik laser $\mathrm{CO}_{2}$. Penelitian ini bermanfaat untuk mengetahui apakah benar olahraga dapat menurunkan kadar glukosa dalam darah. Hipotesa penelitian ini adalah konsentrasi gas aseton pada gas hembus seseorang setelah berjalan di atas treadmill lebih rendah dibandingkan dengan konsentrasi gas aseton pada gas hembus orang tersebut sebelum berjalan di atas treadmill. .

\section{B. TINJAUAN PUSTAKA}

1. Gas Aseton dalam Napas Manusia
Terdapat banyak gas penanda biologis dalam napas manusia, beberapa diantaranya adalah isoprena, aseton, etana dan metanol (Cao, 2006).

Gas aseton $\left(\mathrm{C}_{3} \mathrm{H}_{3} \mathrm{O}\right)$ yang juga dikenal sebagai propanon merupakan senyawa organik yang mudah menguap, tidak berwarna dan memiliki massa molar 58,08 $\mathrm{g} / \mathrm{mol}$. Aseton merupakan hasil eliminasi $\mathrm{CO}_{2}$ dari acetoacetate,

$\mathrm{CH}_{3} \mathrm{COCH}_{2} \mathrm{COOH} \rightarrow \mathrm{CH}_{3} \mathrm{COCH}_{3}+\mathrm{CO}_{2}$.

Di dalam tubuh manusia, aseton dihasilkan melalui proses pemecahan lemak (lipolisis), diserap ke dalam aliran darah dan dikeluarkan melalui alveoli paru-paru saat bernapas. Dalam keadaan normal, konsentrasi aseton di dalam tubuh relatif stabil. Konsentrasi aseton bervariasi dari 0,5 ppmV untuk orang sehat hingga ratusan ppmV untuk penderita diabetes melitus akut (Mathew, dkk., 2015). Konsentrasi gas aseton dalam napas ini tidak dipengaruhi oleh jenis kelamin, umur maupun indeks massa tubuh (IMT) (Schwarz, dkk., 2009).

\section{Manfaat Olahraga terhadap Penurunan Konsentrasi Gas Aseton}

Dalam dunia medis, olahraga dianggap sebagai aktivitas fisik yang efeknya dapat diukur. (Cinar, dkk., 2013). Olahraga tidak hanya membuat badan menjadi bugar, tetapi juga dapat mencegah penyakit 
bahkan dapat dijadikan sebagai terapi penyakit kronis. Olahraga dapat mengurangi resistansi insulin dan membantu proses regulasi glukosa darah sehingga sangat dianjurkan untuk penderita diabetes melitus dan yang berpotensi menderita diabetes melitus (Hordern, 2011; Banfi, dkk., 2012).

Olahraga terdiri dari tiga tahap, yaitu: pemanasan, inti dan pendinginan. Tahap pertama berupa pemanasan selama 5-10 menit untuk mempersiapkan tubuh melakukan olahraga inti. Tahap kedua berupa olahraga inti, yang merupakan bagian pokok dari olahraga yang dilakukan selama 20-40 menit. Tahap ketiga berupa pendinginan selama 5-10 menit untuk mengembalikan sistem peredaran darah, syaraf dan metabolisme pada keadaan normal (Cinar, dkk., 2013).

Salah satu jenis olahraga yang dianjurkan untuk penderita diabetes melitus adalah erobik. Selama melakukan erobik, terjadi oksidasi glukosa, asam amino dan asam lemak di dalam mitokondria. Asam lemak diangkut menuju mitokondria dan didegradasi menjadi acetyl-CoA.

Glikolisis mengubah glukosa menjadi pirufat dan dengan adanya oksigen di dalam sel, pirufat dioksidasi menjadi acetyl-CoA. Degradasi asam amino juga mengakibatkan pembentukan acetylCoA. acetyl-CoA yang diproduksi selama melakukan erobik digunakan untuk memproduksi adenosine triphosphate (ATP). ATP merupakan sumber energi utama sel. Sintesis ATP di dalam mitokondria tidak akan terjadi jika tidak ada oksigen. Contoh erobik adalah berjalan kaki dan bersepeda (Cinar, dkk., 2013).

\section{Analisis Gas Hembus}

Metode analisis gas hembus memiliki beberapa keunggulan, diantaranya adalah: bersifat noninvasive (tidak menyakitkan); dapat dilakukan berulang-ulang dan dapat dilakukan di semua usia. Selain itu, analisis gas hembus dapat memberikan informasi langsung mengenai fungsi pernapasan yang tidak mungkin diperoleh dengan cara lain. Analisis konsentrasi gas aseton dapat dijadikan sebagai alat diagnosis pendamping dan juga alat deteksi dini penyakit diabetes mellitus (Mathew, dkk., 2015).

Penelitian

mengenai konsentrasi gas aseton pada gas hembus orang yang berolahraga pernah dilakukan oleh Senthilmohan, dkk. (2000). Mereka meneliti konsentrasi gas aseton pada gas hembus orang yang berlari, menggunakan metode SIFT-MS (selected ion flow mass spectrometry). Konsentrasi gas aseton yang didapatkan bervariasi pada rentang 100-1400 ppbV. Konsentrasi gas aseton pada sebagian besar relawan bertambah selama melakukan olahraga lari. Bertambahnya konsentrasi gas aseton pada gas hembus menandakan bahwa 
terjadi pengeluaran gas aseton dari dalam tubuh.

Mitrayana (2008) mendeteksi gas aseton dari gas hembus pernapasan melalui mulut menggunakan spektrometer fotoakustik konfigurasi intrakavitas dengan sumber radiasi laser $\mathrm{CO}_{2}$. Konsentrasi gas aseton penderita diabetes melitus dibandingkan dengan konsentrasi gas aseton orang sehat, sehingga penyakit dapat dideteksi secara dini.

Pratama (2011) mengukur konsentrasi gas aseton pada sampel napas pasien penderita diabetes melitus tipe-2 dan relawan sehat sebagai kontrol. Konsentrasi gas aseton diukur menggunakan spektrometer fotoakustik laser $\mathrm{CO}_{2}$ konfigurasi intrakavitas. Hasil konsentrasi terendah gas aseton pada pasien diabetes melitus tipe- 2 sebesar $540 \pm 6$ ppbV dan tertinggi sebesar $1050 \pm 6$ ppbV, sedangkan pada relawan sehat, konsentrasi gas aseton tertinggi sebesar $520 \pm 6 \mathrm{ppbV}$.

Perbedaan antara metode SIFT-

MS dengan metode spektroskopi fotoakustik adalah bahwa metode SIFT-MS dalam mendeteksi sampel berdasarkan pada proses ionisasi (Senthilmohan, dkk., 2000). Metode spektroskopi fotoakustik dalam mendeteksi sampel berdasarkan pada terjadinya resonansi energi antara sumber radiasi dengan energi eksitasi molekul sampel (Amin, 2012).

\section{Spektrometer Fotoakustik}

Spektrometer fotoakustik mendeteksi sampel berdasarkan pada terjadinya resonansi energi antara sumber radiasi dengan energi eksitasi molekul sampel. Selanjutnya molekul yang tereksitasi dikondisikan agar meluruh secara termal, kemudian diubah menjadi sinyal fotoakustik yang mencirikan konsentrasi sampel. Hal tersebut membuka peluang dilakukannya pendeteksian sembarang sampel asalkan energi eksitasinya sesuai dengan energi sumber radiasi dan mekanisme peluruhannya secara termal (Amin, 2012).

\section{METODE PENELITIAN}

\section{Tempat dan Waktu Penelitian}

Penelitian ini dilakukan di Laboratorium Atom Inti FMIPA Universitas Gadjah Mada Yogyakarta pada bulan OktoberDesember 2015.

\section{Alat Penelitian}

Peralatan yang digunakan dalam penelitian ini adalah spektrometer fotoakustik laser $\mathrm{CO}_{2}$, sistem aliran gas dan treadmill.

\subsection{Spektrometer fotoakustik laser $\mathrm{CO}_{2}$}

Spektrometer fotoakustik laser $\mathrm{CO}_{2}$ digunakan untuk mendeteksi konsentrasi gas aseton. Spektrometer fotoakustik laser $\mathrm{CO}_{2}$ terdiri dari tabung laser, sumber tegangan laser, cell fotoakustik, chopper, grating, 
lensa intrakavitas, cermin keluaran, penguat lock-in, meter daya, ADC, PC, pompa air dan pompa vakum.

\subsection{Sistem sampling dan aliran gas}

Sistem sampling dan aliran gas terdiri sample bag, selang, scrubber, regulator tabung gas dan meter aliran.

\subsection{Treadmill}

Treadmill digunakan untuk berolahraga oleh relawan yang diteliti konsentrasi gas aseton pada gas hembus pernapasannya.

\section{Bahan Penelitian}

Bahan-bahan yang digunakan dalam penelitian ini adalah:

a. Gas $\mathrm{CO}_{2}, \mathrm{~N}_{2}$ dan $\mathrm{He}$ dengan konsentrasi $99 \%$ sebagai medium aktif laser $\mathrm{CO}_{2}$. Disamping itu, gas $\mathrm{N}_{2}$ juga digunakan untuk membersihkan cell fotoakustik dan menentukan sinyal latar.

b. Sampel gas hembus orang yang berolahraga di atas treadmill.

c. Aquades untuk mendinginkan tabung laser $\mathrm{CO}_{2}$.

d. Alkohol untuk membersihkan kuvet.

\section{Langkah Penelitian}

Langkah untuk mengukur konsentrasi gas aseton pada gas hembus orang yang berjalan di atas treadmill menggunakan spektrometer fotoakustik laser $\mathrm{CO}_{2}$ adalah sebagai berikut: a. Melakukan pengambilan sampel gas hembus dengan cara meminta setiap relawan untuk menghembuskan napas secukupnya ke dalam sample bag melewati scrubber $\mathrm{KOH}$ dan $\mathrm{CaCl}_{2}$ sebelum berolahraga, setelah melakukan pemanasan, setelah melakukan olahraga inti, setelah melakukan pendinginan dan 5 menit setelah berolahraga.

- Pemanasan dilakukan dengan cara berjalan di atas treadmill dengan kecepatan $1,2 \mathrm{~km} /$ jam selama 5 menit.

- Olahraga inti dilakukan dengan cara berjalan di atas treadmill dengan kecepatan 2,4 $\mathrm{km} / \mathrm{jam}$ selama 20 menit.

- Pendinginan dilakukan dengan cara berjalan di atas treadmill dengan kecepatan $1,2 \mathrm{~km} / \mathrm{jam}$ selama 5 menit.

b. Mengalirkan sampel dari sample bag ke dalam cell fotoakustik.

c. Mengukur sinyal fotoakustik beserta daya lasernya untuk setiap sampel.

d. Menganalisis data untuk memperoleh konsentrasi gas aseton pada setiap sampel menggunakan kurva linieritas.

e. Membandingkan konsentrasi gas aseton sebelum dan setelah berjalan di atas treadmill menggunakan persamaan (4.2)

$$
\Delta C=\frac{c_{0}-c_{i}}{c_{o}} \times 100 \%(4.2) .
$$


$\Delta C$ merupakan penurunan konsentrasi gas aseton setelahberjalan di atas treadmill ( $C_{i}$ ) dibandingkan dengan konsentrasi gas aseton sebelum berjalan di atas treadmill $\left(C_{o}\right)$.

f. Membandingkan konsentrasi gas aseton orang yang berjalan di atas treadmill dengan konsentrasi gas aseton orang diam.

D. HASIL DAN PEMBAHASAN

Pengukuran Konsentrasi Gas Aseton pada Gas Hembus Orang yang Berjalan di atas Treadmill
Hubungan antara sinyal fotoakustik ternormalisasi terhadap konsentrasi gas aseton, ditunjukkan oleh Gambar 1. Grafik ini menunjukkan kurva linieritas dengan persamaan $y=0,0119 x+0,0193$ dengan faktor korelasi sebesar $R^{2}=0,9743$.

Grafik konsentrasi gas aseton pada gas hembus orang yang berjalan di atas treadmill ditunjukkan oleh Gambar 2.

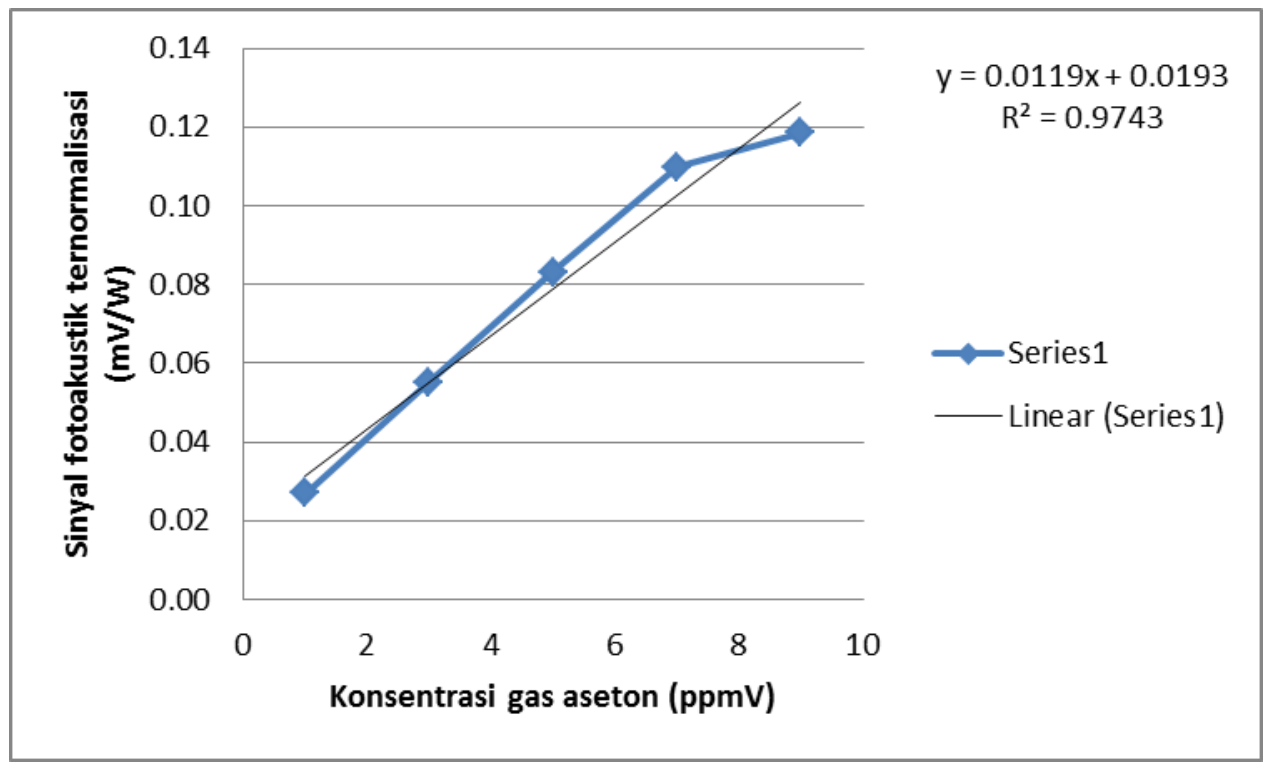

Gambar 1. Kurva Linieritas Gas Aseton 


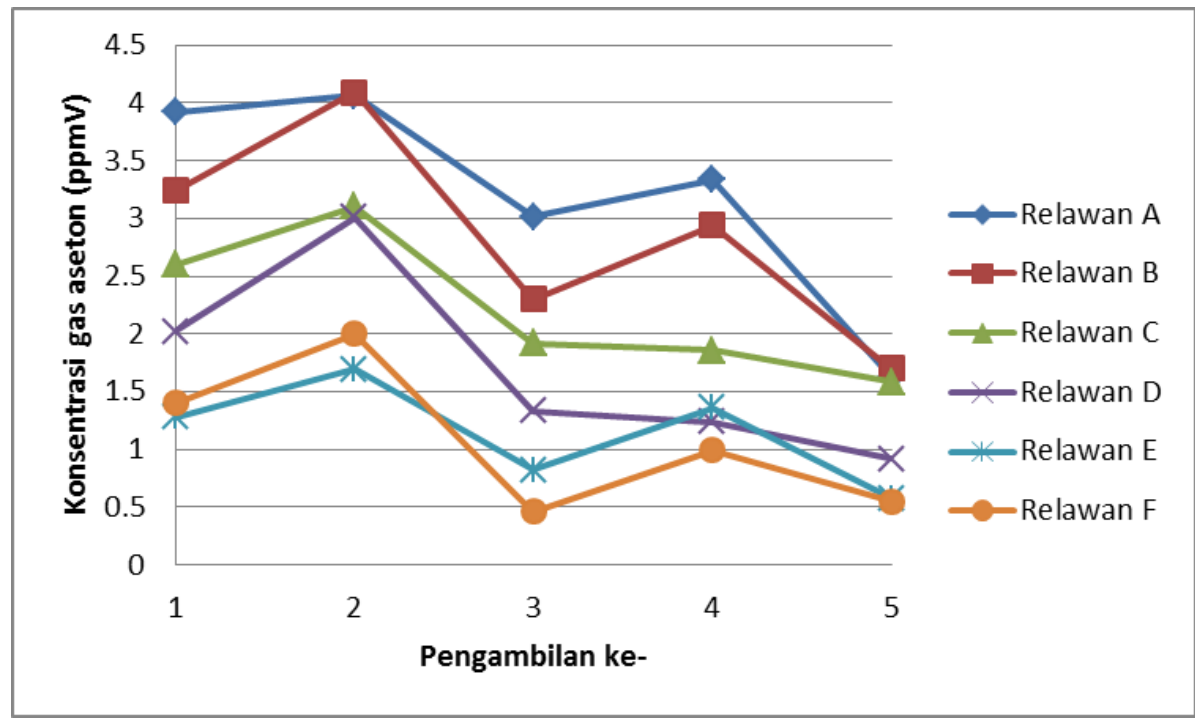

Gambar 2.Grafik Konsentrasi Gas Aseton pada Gas Hembus Orang yang Berjalan di atas Treadmill.

Gambar 2 menunjukkan bahwa grafik konsentasi gas aseton dari keenam relawan memiliki kecenderungan yang sama. Grafik konsentrasi gas aseton pada gas hembus orang yang berjalan di atas treadmill dibandingkan dengan grafik konsentrasi gas aseton pada gas hembus orang diam. Grafik konsentrasi gas aseton pada gas hembus orang diam cenderung datar seperti yang ditunjukkan oleh Gambar 3. Pengambilan sampel gas hembus orang diam juga dilakukan sebanyak lima kali dengan interval waktu yang sama dengan pengambilan sampel gas hembus orang yang berjalan di atas treadmill.

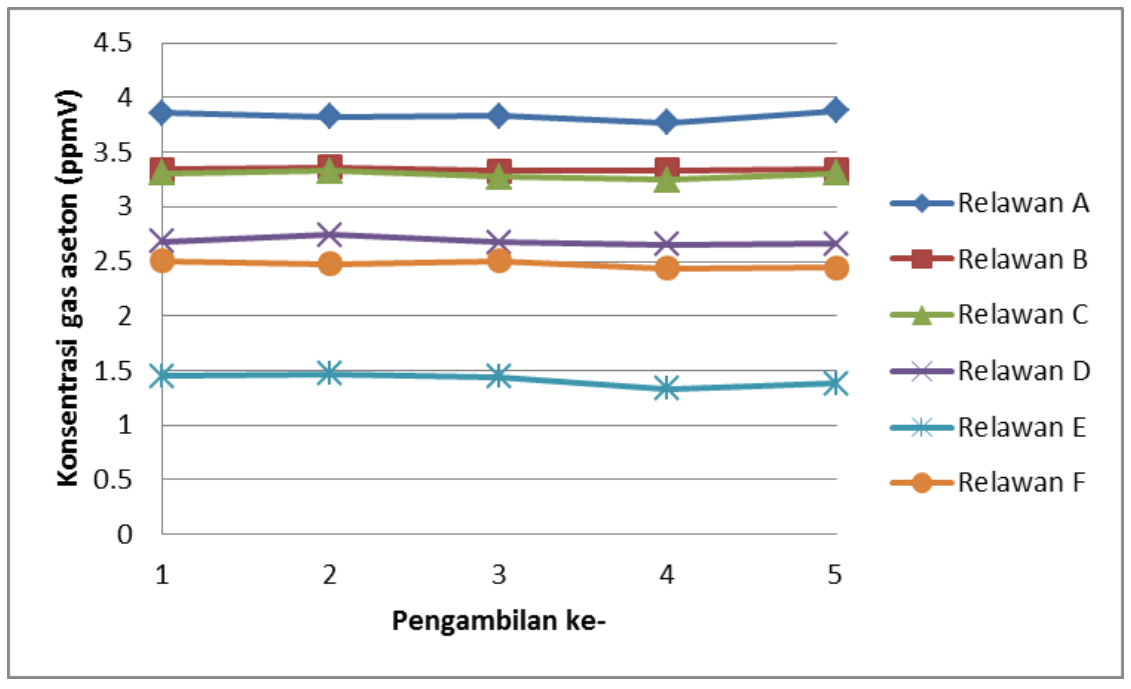

Gambar 3. Grafik Konsentrasi Gas Aseton pada Gas Hembus Orang Diam 
Konsentrasi gas aseton orang yang berjalan di atas treadmill lebih fluktuatif dibandingkan dengan konsentrasi gas aseton orang diam karena menurut Alan (2000) konsentrasi gas aseton dipengaruhi oleh kadar glukosa di dalam darah. Menurut Nayak (2005) kadar glukosa di dalam darah dapat dipengaruhi oleh olahraga. Seperti yang terlihat pada Gambar 2, pada pengambilan sampel kedua, yaitu setelah melakukan pemanasan, konsentrasi gas aseton meningkat dibandingkan dengan sebelum berolahraga. Pemanasan dilakukan selama 5 menit, menurut Nayak (2005) berolahraga selama kurang dari 20 menit menyebabkan hati melepaskan glukosa yang disimpan untuk bahan bakar, meningkatnya konsentrasi gas aseton dimungkinkan karena glukosa yang dilepaskan oleh hati masih berada di dalam tubuh sehingga ketika dideteksi melalui pernapasan menunjukkan sinyal fotoakustik yang tinggi. Pada pengambilan sampel ketiga, yaitu setelah melakukan olahraga inti, konsentrasi gas aseton turun drastis, lebih rendah dari sebelum berolahraga. Olahraga inti dilakukan selama 20 menit, menurut Nayak (2005) berolahraga selama 20 menit atau lebih menyebabkan otototot mengambil glukosa untuk bahan bakar dan menurunkan kadar glukosa darah secara keseluruhan. Pada pengambilan sampel keempat, yaitu setelah melakukan pendinginan, konsentrasi gas aseton kembali naik, tetapi tidak setinggi seperti setelah melakukan pemanasan. Kenaikan ini dimungkinkan karena hati kembali melepaskan glukosa yang disimpan, tetapi glukosa tersebut masih terdapat di dalam tubuh, belum digunakan oleh otot untuk bahan bakar, sehingga menunjukkan kenaikan sinyal fotoakustik ketika dideteksi. Lima menit setelah berolahraga konsentrasi gas aseton lebih rendah dibandingkan sebelum berolahraga. Konsentrasi gas aseton pada gas hembus orangsetelah berjalan di atas treadmill mengalami penurunan sebesar $38 \%$ hingga $60 \%$ dibandingkan dengan sebelum berjalan di atas treadmill.

Hal ini sesuai dengan hipotesa yang menyatakan bahwa konsentrasi gas aseton pada gas hembus seseorang setelah berjalan di atas treadmill lebih rendah dibandingkan dengan konsentrasi gas aseton pada gas hembus orang tersebut sebelum berjalan di atas treadmill karena olahraga dapat menurunkan kadar glukosa dalam darah.

\section{E. KESIMPULAN DAN SARAN \\ 1. Kesimpulan}

Kesimpulan penelitian ini adalah bahwa konsentrasi gas aseton pada gas hembus orang setelah berjalan di atas treadmill mengalami penurunan sebesar $38 \%$ hingga $60 \%$ dibandingkan dengan sebelum berjalan di atas treadmill. 


\section{Saran}

Saran untuk penelitian selanjutnya adalah sebagai berikut:

a. Relawan yang diambil sampel napasnya pada penelitian selanjutnya diupayakan penderita diabetes melitus dengan didampingi oleh tenaga medis, sehingga dihasilkan dosis olahraga yang tepat untuk penderita diabetes melitus.

b. Selain dilakukan pengukuran konsentrasi gas aseton, juga dilakukan pengukuran kadar glukosa darah, untuk mengetahui pengaruh olahraga pada perubahan kadar glukosa darah secara langsung.

\section{F. DAFTAR PUSTAKA}

Alan, G.G., 2000, Lipid MetabolismSynthesis and Oxidation, Biochemical and Physiological Aspect of Human Nutritio, 3305.

Amin, M.N., 2012, Kinerja Spektrometer Fotoakustik dalam Karakterisasi Scrubber Gas $\mathrm{C}_{2} \mathrm{H}_{4}$, Tesis, Universitas Gadjah Mada.

Banfi, G., Colombi, A., Lombardini, G. dan Lubkowska, A., 2012, Metabolic markers in sports medicine, Adv Clin Chem, Vol. 56, pp. (1-54).

Cao, W. dan Yuan, D., 2006, Breath Analysis: Potential for Clinical Diagnosis and Exposure Assessment, Clinical Chemistry 52, No. 5.
Cinar, Y., Demirci, H. dan Satman, I., 2013, Principle of Exercise and Its Role in the Management of Diabetes Mellitus, http://dx.doi.org/10.5772/5050 3 .

Hordern, M.D., Dunstan, D.W., Prins, J.B., Baker, M.K., Singh, M.A.F. dan Coombes, J.S., 2011, Exercise Prescription for Patients with Type 2 Diabetes and Pre-diabetes: A position statement from Exercise and Sport Science Australia, Journal of Science and Medicine in Sport 15. 25-31.

Mathew, T.L., Pownraj, P., Abdulla, S., Pullithadhatil.B., 2015, Technologies for Clinical Diagnosis Using Expired Human Breath Analysis, Diagnostics, 5, 27-60.

Mitrayana, 2008, Rancang Bangun Spektrometer Fotoakustik dan Spektrometer Modulasi Panjang Gelombang Laser, Kajian Deteksi Gas Biomarker $\mathrm{C}_{2} \mathrm{H}_{4}, \mathrm{C}_{3} \mathrm{H}_{6} \mathrm{O}, \mathrm{NH}_{3}, \mathrm{NO}_{2}$ dan NO dalam bidang Kedokteran, Disertasi, Universitas Gadjah Mada.

Nayak, S., 2005, Influence of Aerobic Treadmill Exercise on Blood Glucose Homeostasis in Noninsulin Dependent Diabetes Mellitus Patients, Indian Journal of Clinical Biochemistry, 20(1):47-51. 
Pratama, Y., 2011, Optimasi Daya Laser pada Spektrometer $\begin{array}{lll}\text { Fotoakustik Laser } & \mathrm{CO}_{2}\end{array}$ Konfigurasi Intrakavitas dan Aplikasinya dalam Mengukur Konsentrasi Gas Aseton pada Gas Hembus Napas Pasien Penderita Diabetes Melitus Tipe 2, Tesis, Universitas Gadjah Mada.

Schwarz, K., Pizzini, A., Arendacka, B., Zerlauth, K., Filipiak, W., Dzien, A., Neuner, S., Lechleitner, M., Scholl-Burgi, S., Miekisch, W., Schubert, J., Unterkofler, K., Witkovsky, V., Gastl, G., dan Amann, A.,
2009, Breath Acetone Aspects of NormalPhysiology Related to Age and Gender as Determined in a PTR-MS Study, Journal of Breath Research.

Senthilmohan, S.T., Milligan, D.B., Mc Ewan, M.J., Freeman, C.G., dan Wilson, P. F., 2000, Quantitative Analysis of Trace Gases of Breath during Exercise Using the New SIFT MS Technique, Redox Rep. 151-3. 